\title{
BRINGING CREATIVE ECONOMY TO COMMUNITY RESILIENCE TOWARDS BETTER URBAN GOVERNANCE
}

\author{
The Case of Semarang City, Indonesia
}

Prihadi NUGROHO, Department of Urban and Regional Planning UNDIP; Indonesia

\begin{abstract}
As a growing metropolis in the north coast Java region, Semarang City has been transforming from a port city to a multifunctioning city. Mercantilism tradition has brought forward the local economy into trade and service dominance, shifting the city to become an important marketplace beyond the peripheral boundaries. Interestingly, the city's urbanisation growth does not follow 'a common trend' in Indonesia (and many parts of the world) characterized by modernized urban fabrics with mixed land use. The city is suffered from fragmented physical urban transformation and separated formal and informal economy. The urban sprawling forces are scattered around the city outskirt while the inner city's development filled up by discontinued commercial properties. On the other hand, there is 'a new direction' of urban movement based on the bottom-up kampong revitalisation. Instead of encouraging more modernized physical and economic space, these kampong settlements have proposed creative economy from below useful to (reJorganising the economic space of the urban region. This paper aims to examine how the recent urban transformation in Semarang City has been fuelled by creative economy activities through which the kampong settlements promote local community resilience. Desk study method accompanied by focus group discussions and field observations is completed in pursuit of data collection and analysis. The primary data source is taken from the Local Development Planning Authority project on creative kampong development since 2016. The preliminary results show that kampong-based creative economy movement at the urban scale is beneficial to enhancing the informal economy and urban settlement development. Participatory governance has been strengthened following income generation in situ even though their contribution to community resilience in the long-term still requires further explorations.
\end{abstract}

\section{Keywords}

Creative economy, community resilience, kampong revitalisation, Semarang City

\section{Introduction}

As a growing metropolis in the north coast Java region, Semarang City has been transforming from a port city to a multifunctioning city. Located next to the Java Sea, the early urban transformation originated from seaport development and coastal settlement in SimonganBergota area since the sixth century. Until the mid-1500s, this area remained the city's sea 
transportation and trading hub when the ruling administration moved the government quarter to the north in Bubakan kampong settlement. For the next half-century, the urban settlements in the northern Semarang developed intensively, occupying the vacant lands resulted from sedimentation towards the Java Sea. This period marked the rise of the city's dual functions of political-economic governance until the present days (Pemerintah Daerah Kotamadya Dati II Semarang, 1979).

The legacy of the Dutch Colonization era (1602-1942) has created social-spatial segregation of urban transformation. A new urban centre built around the former municipal government quarter - currently known as the old city precinct Little Netherlands - and surrounded by well-developed urban settlements for the upper-to-middle class society including the Dutch officials and European nationalities (first class), and the foreign class of Chinese, Arab, and India (second class). Meantime, the lower class society belonged to pribumi (indigenous) citizens who lived in slum kampong settlements outside the urban centre and suburbs. Later, a new residential area built for the upper-class citizens in the hilly Candi area of the Upper Semarang, particularly due to cholera and malaria outbreaks for nearly two decades until 1918 and increased population density in the Lower Semarang area (Pemerintah Daerah Kotamadya Dati II Semarang, 1979; Amalia, Purnomo and Shokheh, 2016; Nugroho, 2016).

To date, a mixed urban land-use in the urban centre surrounded by unorganised kampong settlement pattern has featured the contemporary Semarang city landscape. Mercantilism tradition has brought forward the local economy into trade and service dominance, shifting the city to become an important marketplace beyond the peripheral boundaries. Although the manufacturing industry has remained the leading sector in forming Gross Regional Domestic Product (GRDP) with more than 26 percent share, its contribution tends to decline annually. On the contrary, the share of the trading sector (14 percent) and service sector (16 percent) are growing steadily. Together with the population growth rate at 1.6 percent per annum, the local economic change has accelerated urbanisation pressures across the city. Increased growth of population density from 3.343 lives $/ \mathrm{km}^{2}$ (1990) to 4,628 lives $/ \mathrm{km}^{2}$ (2017) has accelerated urban land conversion to built-up area side-by-side with the economic performance growth (Badan Pusat Statistik Kota Semarang, 2018). Therefore, this paper aims to examine how the recent urban transformation in Semarang City has been fuelled by creative economy activities through which the kampong settlements promote local community resilience.

\section{Methods}

\subsection{Data collection}

This research collected data primarily from secondary sources of government publications (i.e., policies, regulations, statistics, and project reports), previous studies, and media news using a desk study method. Badan Perencanaan Pembangunan Daerah (Local Development Planning Authority/Bappeda) of Semarang City Government was of the key informant in providing those secondary data and facilitating focus group discussion (FGD). The local development policies included for analysis were Rencana Pembangunan Jangka Panjang Daerah (Long-term Development Plan/RPJPD) of Semarang City Year 2005-2025, Rencana Pembangunan Jangka Menengah Daerah (Mid-term Development Plan/RPJMD) of Semarang City Year 2000-2005, 2005-2010, 2010-2015, 2016-2021 (RPJMD-2000, RPJMD-2005, RPJMD- 
2010, RPJMD-2016), Rencana Induk (Masterplan) of Semarang City Year 1975-2000 (RIK1975), Rencana Tata Ruang Wilayah (Spatial Plan) of Semarang City Year 1995-2005, 20002010, and 2011-2031 (RTRW-1995, RTRW-2000, and RTRW-2011). A number of regulations concerned with kampong improvement/revitalisation, creative economy, and city resilience were examined and triangulated with previous studies and media news as well.

After completing the desk study phase, the acquired knowledge was verified through FGD and field observations. Both were undertaken by involving multiple stakeholders, i.e., the local kampong activists, village leaders, business entrepreneurs, Kelompok Sadar Wisata (Tourism Activist Group/Pokdarwis), Pembinaan Kesejahteraan Keluarga (Women's Group on Family Welfare Improvement/PKK), youth groups, community-based organisations (CBOs), and government agencies. This phase focused on 10 out of 177 creative kampong development projects initiated by Bappeda since 2016. Such combined data collection was expected to provide a fuller understanding of the creative economy project at the city level.

\subsection{Methods of analysis}

Content analysis and descriptive statistical analysis were completed to examine all those data collected through desk study method. Both focused on examining the patterns of urbanisation trend in terms of demographic and land-use change, urban sprawling forces, and the government interventions on directing spatial development and controlling the urban development impacts. Policy coordination and consistency were of the important issue during the research so that the implementation of policies and regulations associated with the urban transformation became critical to the rise and persistence of kampong-based creative economy movement. Subsequently, the case study method applied to explore how the kampong communities respond towards the impacts, particularly their initiatives on reforming the urban fabrics. Their struggle and adaptive capacity to maintain the urban kampong livelihood were interesting to feedback the future urban development policies.

\section{Results and Discussion}

\subsection{Demographic profile of the urbanisation trend}

Population size in Semarang City has been growing rapidly for the last five decades. The size recorded in population censuses was 646,590 inhabitants (1971) and rose to $1,024,940$ (1980), 1,249,230 (1990), 1,348,803 (2000), and 1,555,984 (2010). In 2018, it was 1,668,578 inhabitants and predicted to reach 2,100,000 by 2030 (Biro Pusat Statistik, 1962, 1972; Badan Pusat Statistik Kota Semarang, 1982, 1991, 2001, 2012; Handayani and Rudiarto, 2014; Badan Pusat Statistik Provinsi Jawa Tengah, 2018). As shown in Figure 1, the increasing population trend occurred at declining growth rate from 2.83 percent (1961-1971) to 0.70 percent (2010-2018) annually, with exception to the period of 1971-1980 when it reached 5.25 percent due to territorial extension in 1976. Referring to Peraturan Pemerintah (Government Regulation) of the Government of Indonesia No. 16 Year 1976 about Territorial Extension of Semarang City Administrative Boundaries, the city's region was extended to include additional kecamatan (subdistrict) and desa/kelurahan (village) of the neighboring Kendal Regency (2 subdistricts, 24 villages), Semarang Regency (2 subdistricts, 26 villages), and Demak Regency (1 subdistrict, 16 villages). Consequently, Semarang City extended from $99.41 \mathrm{~km}^{2}$ (1950) to $364.81 \mathrm{~km}^{2}$ (1976) and $373.70 \mathrm{~km}^{2}$ (1990-present) consisting of 16 
subdistricts and 177 villages (Pemerintah Republik Indonesia, 1976; Nugroho, 2016; Badan Pusat Statistik Kota Semarang, 2018).

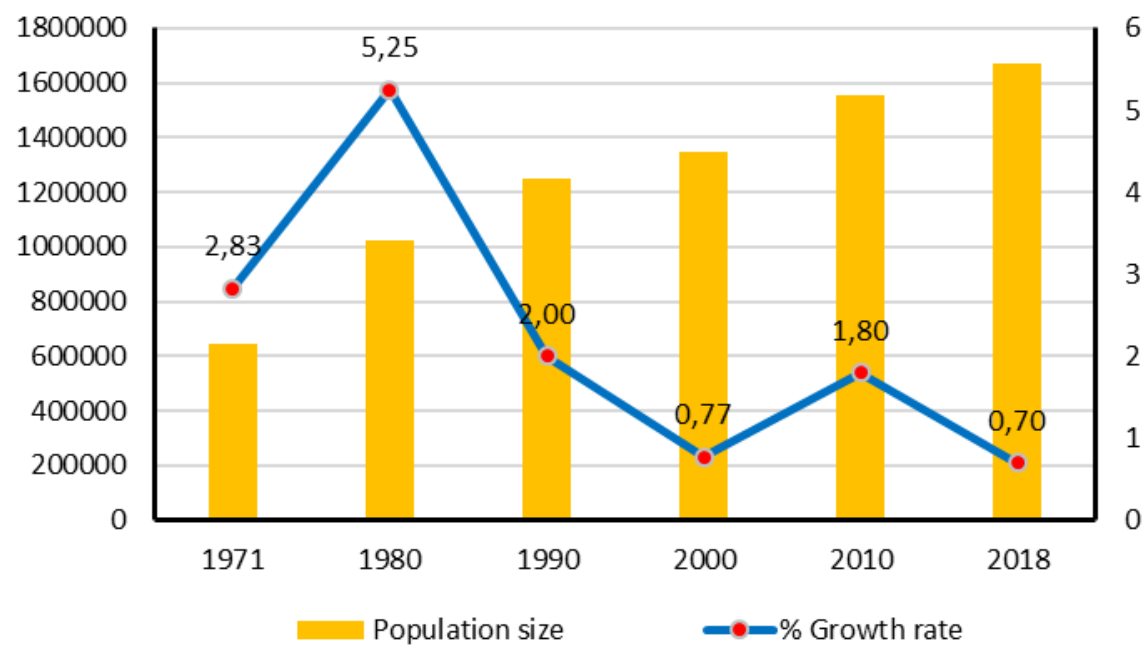

Figure 1 Population size and growth in Semarang City, 1971-2018

Source: Biro Pusat Statistik (1962, 1972), Badan Pusat Statistik Kota Semarang (1982, 1991, 2001, 2012), Badan Pusat Statistik Provinsi Jawa Tengah (2018)

Such territorial extension has led to a significant change of the city's demographic profile. In 1971 , the city population lived in an urban area but since territorial extension around 20 percent was living in a rural area (1980-1990), especially in the extended peripheral regions of Semarang City. However, such phenomenon lasted shortly for two decades when the urban population has increased faster to reach more than 90 percent since the 2000s at the lower growth rate (Figure 2).

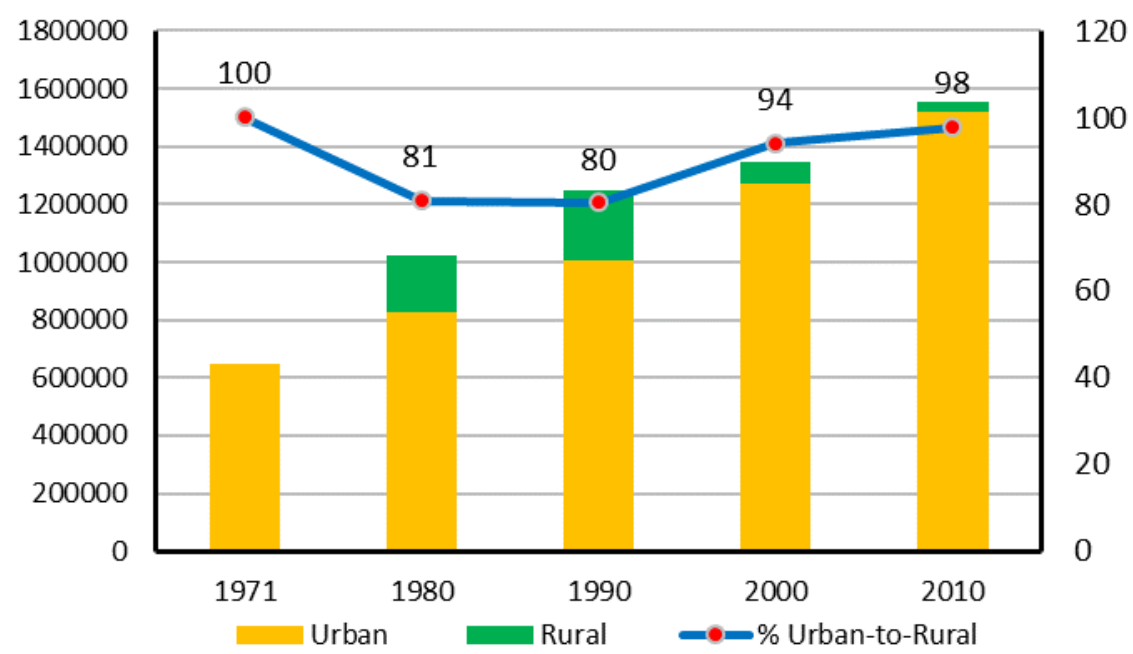

Figure 2 Urban and rural population growth in Semarang City, 1971-2010

Source: Biro Pusat Statistik (1962, 1972), Badan Pusat Statistik Kota Semarang (1982, 1991, 2001, 2012) 


\subsection{Urban land-use change and sprawling phenomenon}

Land conversion from agriculture and rural land to the built-up area is an immediate impact of urbanisation trend in Semarang City. Intensified land use change concentrates on the city centre area, started from the former central business district (CBD) growth triangle JoharPemuda-Simpang Lima and dispersed towards the urban fringes, i.e., East Semarang, Genuk, and Pedurungan Subdistricts (east-southeast zone), Banyumanik and Tembalang Subdistricts (south-southwest zone), and West Semarang and Tugu Subdistricts (west zone). Typical landuse change of Semarang City represents radial-concentric pattern when the urban growth spreads out along the axial primary roads and new urban settlements and commercial zones which emerged sporadically close to the existing settlements.

Since the late 1990s, the unorganized urban growth pattern has become prominent in the following years. Initially, both RIK-1975 and RTRW-1995 have divided clearly the urban land parcels into different land use zones. The urban growth direction was plotted to the eastwest for industrial development zones supported by low-density settlements in Genuk and Tugu Subdistricts, and to the southeast-south for miscellaneous urban services supported by medium-density settlements. The southwestern part of Semarang City was restricted for the built-up area development and preserved for the water catchment area supported by lowdensity settlements in Gunungpati and Mijen Subdistricts. Meantime, the CBD development remained to concentrate around the city's growth triangle area consisting of the earliest subdistricts, i.e. East Semarang, West Semarang, Central Semarang, North Semarang, and South Semarang Subdistricts, for mixed land use functions of commercial, public services, transportation hubs, and high-density settlements. In practice, the local government policy shift and massive capital investment accelerated land conversion responding the pursuit of the city's long-term vision to become a modernized metropolis underpinned by religious, orderly, and cultured society by 2025 . New town development to build a satellite city in the peripheries, new growth centres in the suburbs, large scale housing projects, industrial estate development projects, and commercial building blocks were built across the city scatteredly. The absence of sound zoning regulation and strict law enforcement of building permit made the urban growth uncontrolled, leaving the development control interrupted by the conflicting interests of private investors, neighbourhood communities, and individuals. As a result, the urban sprawling phenomenon has unavoidably occupied the agriculture and rural areas, green open spaces, and vacant or less productive lands.

Figure 3 illustrates the phenomenon clearly where the development of built-up areas in the peripheries is poorly unanticipated, causing the urban discontinuum persistence. Numerous landed housing projects built by private developers and individuals outnumbered the public housing projects. Following the land rent curve law, cheaper landed houses (and commercial buildings) were found in the so-called peri-urban areas. Despite supported by adequate public facilities and infrastructure, such sporadic market-based development has promoted a dual-face urban form portraying a disharmonious mixture of the orderly modernized urban space against the ill-developed peri-urban area and the in-between kampong neighbourhood. Unbalanced public investment has forced population in the peri-urban areas to access the public facilities and infrastructure more expensively. In contrast, the kampong dwellers living around the CBD area have surrendered their livelihood towards poor public goods in the slum neighbourhood. Consequently, the city is suffered from fragmented physical urban transformation and separated formal and informal economy. 


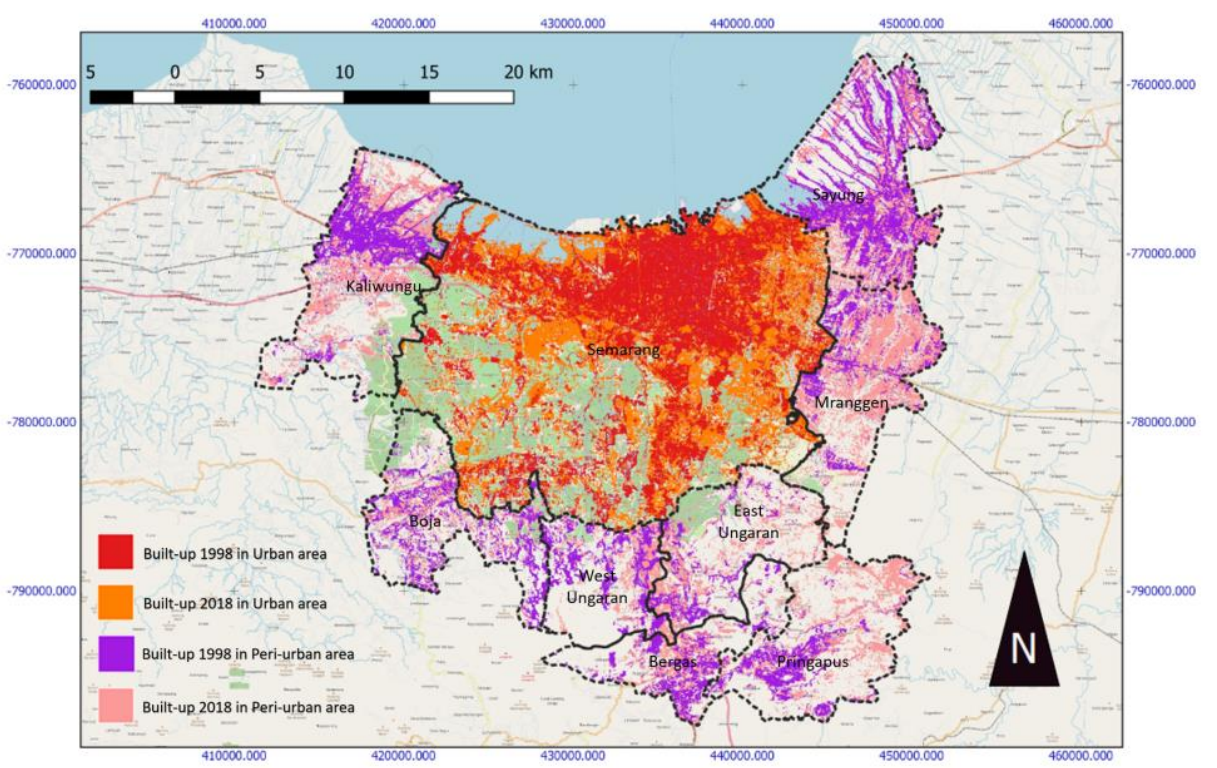

Figure 3 Built-up area growth in Semarang Metropolitan Region, 1998-2018

Source: Sejati, Buchori, and Rudiarto (2019)

\subsection{Implementation of the creative kampong development program}

To overcome urban poverty and slums, the city government introduced a creative kampong development program in 2016. Under the city's mid-term development program called by Gerakan Bersama Penanggulangan Kemiskinan dan Pengangguran Melalui Harmonisasi Ekonomi, Edukasi, Ekosistem, and Etos Bersama Masyarakat (Social Program for Eradicating Poverty and Unemployment through Harmonization of Economic, Education, Ecosystem, and Ethos Aspects of Local Development) - abbreviated with GERBANG HEBAT - the government addressed a kampong-based community empowerment approach to encourage the local residents in designing kampong revitalisation program suitable to the local condition. Hence, each kampong would have a specified thematic kampong development program to promote local uniqueness for household income generation through various social and economic activities such as tourism attraction, local entrepreneurship, and civic engagement.

It was a social innovation program aimed at lowering poverty and unemployment rates, improving slum upgrading, promoting local wisdom for managing potentials and resolving problems at the neighbourhood level, and creating new tourism destinations. The program outputs included the improvement of synergetic collaboration between actors responsible to poverty eradication programs, the integrated implementation of poverty eradication programs, the improved coverage of targeted poverty groups with reference to available poor citizens database, and the achievement of program implementation monitoring. A multidimensional approach was completed to support program implementation through community empowerment of the kampong dwellers to build self-organising groups in coping with the local neighbourhood problems and potentials (social approach); the cultivation of local entrepreneurship atmosphere at the kampong neighbourhood level for stimulating the creation of new business startups (economic approach); beautification of public space in the kampong neighbourhood combined with the improved public facilities and infrastructure 
(physical approach); and civic engagement in building the localized identity and social character (cultural approach).

By 2018, a program evaluation conducted by the local Bappeda found that economic reasoning dominated program implementation ( 53 percent), followed by social ( 35 percent) and infrastructure (12 percent). The economic reasoning was supported by the facts that there were economic potentials driven by the community-based creative economy group and the availability of natural and human resources in each kampong. On the social dimension, the key indicators included community participation, high poverty rate, and the immediate social problems in kampong neighbourhood. For infrastructure concern, the selected kampong featured slum neighbourhood, unorganized settlement pattern, and less green space occupation. In fact, the evaluation, which administered public perception from multiple stakeholders involved in the program implementation, revealed that the most likely goal achievement of the creative kampong development program was local economic sector generation (42 percent). The social empowerment goal posed the second rank (40 percent) and followed by physical kampong improvement (18 percent). This finding indicates that program implementation has fulfilled public expectation (Badan Perencanaan Pembangunan Daerah Kota Semarang, 2018).

The key actors responsible to the program implementation were local entrepreneurs (45 percent), public servants/retired (26 percent), businesspersons (10 percent), housewives (7 percent), industrial employees ( 7 percent), and the others ( 5 percent). Mostly they came from the middle age group 41-55 years ( 48 percent) and the elderly group above 55 years (40 percent) while the youth group below 40 years participated in the program was only 12 percent. They represented various CBOs, i.e, Kelompok Swadaya Masyarakat (Community Self-Organising Group/KSM), PKK, Pokdarwis, small and medium enterprise (SME) group, and youth group with direct support from village and subdistrict government and some external actors from universities, state-owned enterprises, and private companies. Such composition authorised the kampong society to take control of the program implementation from the beginning. Our recent survey has found that the determinants of program implementation are civic engagement (37 percent), business activity (29 percent), public infrastructure provision (22 percent), and external actors' support (12 percent). Surprisingly, the largest budget allocation for realising the program was spent on physical projects. Around 60-75 percent of the program expense was for public facilities and infrastructure upgradings like road access, drainage system, entrance gate, public park and lighting, and mural decoration. The rest expense was for community empowerment projects in forms of various training in business development and entrepreneurship. In fact, the major obstacles that have inhibited the program implementation came from the lack of kampong community capacity in terms of their willingness to participate, knowledge and skills, and technological adaptation. As a result, the program implementation heavily relied on the roles of local champion or smaller community group in driving the overall project planning and implementation from below (Badan Perencanaan Pembangunan Daerah Kota Semarang, 2018).

Of the overall targeted kampongs, 91 kampongs focused on local economic development projects (51 percent), 58 kampongs on environmental conservation projects (33 percent), and 28 kampongs on social development projects (16 percent). The economic projects were generated by the local SMEs and home-based enterprises (HBEs) which produce food and beverages (52 percent), handicraft ( 28 percent), and service (20 percent). In contrast, more homogeneous projects were found in the environmentally-based kampong development 
projects with waste management and urban farming activities, and the social-based projects with children an elderly person caring activities and cultural event attractions. Regardless of thematic focus, all kampongs observed showed social cohesion persistence in daily life. To some extent, they could manage social interactions well but this fact has not contributed directly to their moderate participation in the program implementation. They have realised the importance of civic engagement during the decision-making process from below, but their reluctance to get involved more actively was associated with self-pragmatism to obtain the individual benefits of the program implementation. Hence, the roles of local champion and the elderly group - to whom the kampong society have surrendered the decisionmaking process - have remained dominant in directing it. In turn, such hierarchical social structure has led the creative economy manifestation was overshadowed by these driving actors' interest. Alternatively, their roles were replaced by village government even though it jeopardised the program's spirit of kampong-based community empowerment into topdown structuralist governance.

\subsection{Kampong neighbourhood as an alternative urban space}

The rise of creative economy movement within the recent kampong development program in Semarang City Kampung may provide a solution to fix disharmonious urban space. This could be seen as an evolutionary kampong development program. The first generation called as Kampung Improvement Program (KIP) was introduced during the colonial government in the 1920s as a response towards the Dutch Parliament members of the opposition parties who demanded better living conditions for urban populations in the colonies. Surabaya and Semarang were among the first cities which promoted KIP implementation by the municipal government before it was extended to other cities until the next two decades. In 1969, the Government of Indonesia announced a comprehensive KIP under Rencana Pembangunan Lima Tahun I (the first Five-Year Development Plan/Repelita I) by introducing participatory approach due to the limited resources that the government had to continue the former topdown KIP implementation. Jakarta was the first city which adopted such participatory KIP implementation. These early KIP forms featured physical improvements in the basic urban infrastructure and services within the kampong neighbourhood and funded by foreign lending. Due to the successful achievement of the first generation of KIP, between the 1980s and 1990s, it was extended to secondary cities and smaller towns ('Kampung Improvement Program: Policy Issues and Local', 1989; World Bank, 1995; Reerink and Gelder, 2010).

Distinguished from the early KIP models, the Semarang case has gone further by embedding place bonding of the kampong dwellers with their settlement, economic activities, and social cohesion. The enhanced public facilities and infrastructure in the kampong settlement are likely to increase the residents' sense of belonging and attachment to their neighbourhood due to the increased quality of life (Amalia, Purnomo and Shokheh, 2016). This could be more intensified because of beautification decorative projects on the kampong's public space from which new tourism spots may exist as well. As the local business growing, many more residents will be interested in doing business from their homes, either as a primary or secondary source of income generation. With the support of social cohesion manifested in the local CBOs' activities, collective awareness for maintaining the improved kampong's physical appearance and urban services as well as the local business sustainability may persist.

Unfortunately, the so-called physical improvement in the kampong's settlement utilities and vibrancy does not fit the economic functionalities that the local business demands for. The 
local SMEs and any other home-based enterprises (HBEs) depend on supply chain networks from their close neighbourhood in order to lower their production cost (Harvey, Hawkins and Thomas, 2012; Pratt and Hutton, 2013). They also require specific utilities such as logistic warehouse, workshop, waste treatment unit, parking lots for customers, and marketing gallery, which are commonly attached to their residential homes. In the Semarang case, the program has failed to resolve such basic requirements for the local business. Rather, these issues have remained on the business owners' responsibility to resolve so that in many places this situation has raised social conflicts with the neighbours. The program failure to offset the economic benefits with social amenities could be harmful to community participation and social cohesion. This situation has contributed to lowered or even dysfunctional organisational capacity of the local $\mathrm{CBOs}$ to administer the program implementation.

However, the recent creative kampong development program in Semarang City has founded principle approaches to build community resilience in the kampong neighbourhood. Both direct and indirect impacts resulted from place-based local business and tourism attraction have created an alternative urban space to shelter, work, and foster social cohesion within the embedded society at once. Instead of replacing the former kampong appearance with the modernised urban fabrics, the program supports more integrated networks of urban services by preserving the prevailing social cohesion and place bonding. Local wisdom and uniqueness of the kampong settlement are maintained along with the growing economic viability and organisational capacity of the local $\mathrm{CBO}$ s to further the program sustainability.

\section{Conclusion}

Three years of the program implementation are too short to examine the creative kampong development program in Semarang City to come up with such an overarching conclusion regarding its contribution to theoretical building and evidence-based policymaking. It is too early to claim that such renewed KIP model is successful in slum upgrading and poverty eradication in the city. However, the preliminary results have shown that kampong-based creative economy movement at the urban scale is beneficial to enhancing the informal economy and urban settlement development. The kampong residents can continue their local business without being threatened by the extended urbanisation forces across the city. Rather, could have maintained the on-going informal economy side-by-side with the modern urban sectors. In addition, participatory governance encouraged by the program has been strengthened following income generation in situ even though their contribution to community resilience in the long-term still requires further explorations.

\section{References}

Amalia, Rizky; Purnomo, Arif; Shokheh, Mukhamad (2016) "Kampongverbetering dan Perubahan Sosial Masyarakat Gemeente Semarang Tahun 1906-1942", Journal of Indonesian History, Vol. 5 No. 1, pp. 43-51.

Badan Perencanaan Pembangunan Daerah Kota Semarang (2018) Kajian dan Evaluasi Kampung Tematik di Kota Semarang. Semarang: Badan Perencanaan Pembangunan Daerah Kota Semarang.

Badan Pusat Statistik Kota Semarang (1982) Penduduk Kota Semarang Hasil Sensus Penduduk 
1980. Semarang: Badan Pusat Statistik Kota Semarang.

Badan Pusat Statistik Kota Semarang (1991) Hasil Sensus Penduduk 1990 Kota Semarang. Semarang: Badan Pusat Statistik Kota Semarang.

Badan Pusat Statistik Kota Semarang (2001) Penduduk Kota Semarang Hasil Sensus Penduduk Tahun 2000. Semarang: Badan Pusat Statistik Kota Semarang.

Badan Pusat Statistik Kota Semarang (2012) Hasil Sensus Penduduk 2010 Kota Semarang. Semarang: Badan Pusat Statistik Kota Semarang.

Badan Pusat Statistik Kota Semarang (2018) Kota Semarang dalam Angka Tahun 2018. Semarang: Badan Pusat Statistik Kota Semarang.

Badan Pusat Statistik Provinsi Jawa Tengah (2018) Provinsi Jawa Tengah dalam Angka 2018. Semarang: Badan Pusat Statistik Provinsi Jawa Tengah.

Biro Pusat Statistik (1962) Sensus Penduduk 1961 Republik Indonesia. Jakarta: Biro Pusat Statistik Republik Indonesia.

Biro Pusat Statistik (1972) Sensus Penduduk 1971: Penduduk Diperintji Menurut Propinsi dan Kabupaten/Kotamadya. Jakarta: Biro Pusat Statistik Republik Indonesia.

Handayani, Wiwandari; Rudiarto, Iwan (2014) "Dynamics of Urban Growth in Semarang Metropolitan - Central Java: An Examination Based on Built-Up Area and Population Change", Journal of Geography and Geology, Vol. 6 No. 4, pp. 80-87. doi: 10.5539/jgg.v6n4p80.

Harvey, David C.; Hawkins, Harriet; Thomas, Nicola J. (2012) "Thinking Creative Clusters Beyond the City: People, Places and Networks", Geoforum. Elsevier Ltd, Vol. 43 No. 3, pp. 529539. doi: 10.1016/j.geoforum.2011.11.010.

"Kampung Improvement Program: Policy Issues and Local" (1989) Journal of Planning Education and Research, Vol. 9 No. 1, pp. 79-83. doi: https://doi.org/10.1177/0739456X8900900112.

Nugroho, M. Luthfi Eko (2016) Pergeseran Kebijakan Tata Ruang Kota Semarang 1975-2011: Dari Pembangunan Sektoral Menuju Keterpaduan Ruang, Tesis. Universitas Diponegoro.

Pemerintah Daerah Kotamadya Dati II Semarang (1979) Sejarah Kota Semarang. Semarang: Pemerintah Daerah Kotamadya Dati II Semarang. Available at: http://ebook.perpus.jatengprov.go.id/2018/sejarah-kota-semarang/\#/6.

Pemerintah Republik Indonesia (1976) Peraturan Pemerintah Republik Indonesia Nomor 16 Tahun 1976 tentang Perluasan Kotamadya Daerah Tingkat II Semarang. Jakarta: Pemerintah Republik Indonesia.

Pratt, Andy C.; Hutton, Thomas A. (2013) "Reconceptualising the Relationship Between the Creative Economy and the City: Learning from the Financial Crisis", Cities. Elsevier Ltd, Vol. 33, pp. 86-95. doi: 10.1016/j.cities.2012.05.008.

Reerink, Gustaaf; Gelder, Jean-Louis van (2010) "Land Titling, Perceived Tenure Security, and Housing Consolidation in the Kampongs of Bandung, Indonesia", Habitat International. Elsevier Ltd, Vol. 34 No. 1, pp. 78-85. doi: 10.1016/j.habitatint.2009.07.002.

Sejati, Anang Wahyu; Buchori, Imam; Rudiarto, Iwan (2019) "The Spatio-temporal Trends of Urban Growth and Surface Urban Heat Islands Over Two Decades in the Semarang Metropolitan Region", Sustainable Cities and Society. Elsevier, Vol. 46 (July 2018), p. 101432. doi: 10.1016/j.scs.2019.101432.

World Bank (1995) Enhancing the Quality of Life in Urban Indonesia: The Legacy of Kampung Improvement Program, Indonesia Impact Evaluation Report. Washington, D.C. 